Board of Governors of the Federal Reserve System

International Finance Discussion Papers

Number 902

September 2007

\title{
Exchange Rate Pass-Through to Export Prices: Assessing Some Cross-Country Evidence
}

Robert J. Vigfusson, Nathan Sheets, and Joseph Gagnon

NOTE: International Finance Discussion Papers are preliminary materials circulated to stimulate discussion and critical comment. References in publications to International Finance Discussion Papers (other than an acknowledgment that the writer has had access to unpublished material) should be cleared with the author or authors. Recent IFDPs are available on the Web at www.federalreserve.gov/pubs/ifdp/. This paper can be downloaded without charge from Social Science Research Network electronic library at http://www.ssrn.com/. 


\title{
EXCHANGE RATE PASS-THROUGH TO EXPORT PRICES: ASSESSING SOME CROSS-COUNTRY EVIDENCE*
}

\author{
By \\ Robert Vigfusson, Nathan Sheets, and Joseph Gagnon
}

\author{
Federal Reserve Board \\ Mail Stop 42 \\ 20 th \& C Street, NW \\ Washington, D.C. 20551 \\ Revised: June 2007
}

\begin{abstract}
* The authors thank Joseph Gruber, Karen Johnson, Steven Kamin, Mario Marazzi, Trevor Reeve, John Rogers, and two anonymous referees for helpful comments. Phillip Rescober and Nathan Montgomery provided excellent research support. The views expressed in this paper are solely the responsibility of the authors and should not be interpreted as reflecting the views of the Board of Governors of the Federal Reserve System or of any other person associated with the Federal Reserve System.
\end{abstract}

Corresponding Author: Nathan Sheets, nathan.sheets@frb.gov, Phone: 202-452-3600, Fax: 202-452-6424, mailing address indicated above. 


\begin{abstract}
$\underline{\text { Abstract }}$
A growing body of empirical work has found evidence of a decline in exchange rate pass-through to import prices in a number of industrial countries. Our paper complements this work by examining pass-through from the other side of the transaction; that is, we assess the exchange rate sensitivity of export prices (denominated in the exporter's currency). We first sketch out a streamlined analytical model that highlights some key factors that determine pass-through. Using this model as reference, we find that the prices charged on exports to the United States are more responsive to the exchange rate than is the case for export prices to other destinations, which is consistent with results in the literature suggesting that import price pass-through in the U.S. market is relatively low. We also find that moves in the exchange rate sensitivity of export prices over time have been significantly affected by country and region-specific factors, including the Asian financial crisis (for emerging Asia), deepening integration with the United States (for Canada), and the effects of the 1992 ERM crisis (for the United Kingdom).
\end{abstract}

JEL Classification: E31, F30, F41. 


\section{Introduction}

Much has recently been written on exchange rate pass-through to import prices. Olivei (2002) and Marazzi, Sheets, Vigfusson, et al. (2005) have examined the exchange rate sensitivity of U.S. import prices; Otani, Shiratsuka, and Shirota $(2003,2005)$ have looked at exchange rate pass-through to Japanese import prices; and Campa and Goldberg (2002, 2005), Sekine (2006), Frankel, Parsley, and Wei (2005), and Ihrig, Marazzi, and Rothenberg (2006) estimate exchange rate pass-through to import prices for broad sets of countries. ${ }^{1}$ Taken together, the available empirical evidence (although still not fully settled) suggests that exchange rate pass-through to import prices has declined both in the United States and in a number of other industrial countries. Nevertheless, exactly how widespread this decline has been and what has driven the decline has not been completely pinned down.

As an alternative perspective on these issues, our paper extends this recent work by examining pass-through from the other side of the transaction--that is, we assess the exchange rate sensitivity of export prices (denominated in the exporter's currency). ${ }^{2}$ We do this analysis with an eye toward the implications for import price pass-through in the destination markets, particularly the United States. If import prices in some countries have become less sensitive to the exchange rate, we should find evidence that export prices in some corresponding set of countries have become more sensitive to the exchange rate.

Our paper builds on the well-known pricing-to-market literature (see, for example, Knetter $(1989,1993)$ and Goldberg and Knetter (1997)), which studied the pricing behavior of

\footnotetext{
${ }^{1}$ Frankel, Parsley, and Wei study exchange rate pass-through to the prices of eight narrowly defined imported goods, while the other papers focus on exchange rate pass-through to broader measures of import prices.

${ }^{2}$ Bussiere (2004) has also done work along these lines. He studies the exchange rate sensitivity of both import and export prices for the G-7 countries and probes for evidence of non-linearities.
} 
exporting firms as a way of obtaining greater insight into exchange rate pass-through to import prices and, more generally, into the role of the exchange rate and trade prices in influencing cross-country trade flows and patterns of current account balances..

The major conclusions from our work are three-fold. First, we find evidence that the prices charged on exports to the U.S. market denominated in the exporting-country's currency are more sensitive to the exchange rate than is the case for multilateral export prices (i.e., the prices charged to all markets on average). A related result is that the dollar is found to play a unique role in the determination of the prices of internationally traded goods, apparently reflecting both the dollar's global prominence and the centrality of the U.S. marketplace.

Second, rolling regressions with fixed ten-year windows indicate that the exchange rate sensitivity of multilateral export prices (in terms of the exporter's local currency) has moved up sharply in recent years for the Asian NIEs and Canada. Estimates obtained when five-year windows are used, although somewhat volatile, shed useful light on these results. For the Asian NIEs, the increased export price sensitivity appears to be strongly related to the effects of the Asian financial crisis. For Canada, the sensitivity of export prices seems to depend on the direction of moves in the exchange rate. Given Canada's dependence on U.S. demand (85 percent of the country's exports go to the United States), Canadian exporters appear to cut their prices in the U.S. market when the U.S. dollar is strong but are hesitant to raise their prices when the greenback is weak. In contrast, the exchange rate sensitivity of export prices for Japan, Germany, and the United States has moved much less over the past couple of decades. 
Third, for exports to the United States, profit margins--denominated in the exporter's local currency--have narrowed since the dollar peaked in early 2002. As such, the low level of pass-through in the U.S. market does seem to have taken a toll on profit margins. That said, it remains an open issue as to whether profit margins on exports to the United States are now "too narrow" or margins were unusually high several years ago.

The remainder of this paper is organized as follows. We first consider an analytical framework that highlights some of the factors that are likely to play a role in determining the sensitivity of export prices to the exchange rate. The following section then lays out our empirical strategy and considers some key data. The final two sections present the empirical results and offer some concluding thoughts.

\section{An Analytical Framework}

This section briefly outlines an analytical framework that provides intuition regarding the key economic factors that determine the extent of exchange rate pass-through. We consider a foreign firm that produces a single differentiated product for sale in $\boldsymbol{n}$ segmented markets. The firm and all of its production are located in market 1 . Sales in markets 2 through $\boldsymbol{n}$ are exports. The firm's profits are given by: ${ }^{3}$

$$
\sum_{i=1}^{n} p_{i} q_{i}-C\left[\sum_{i=1}^{n} q_{i}, p d_{1}, p m_{1}\right]
$$

where $\boldsymbol{p}_{\boldsymbol{i}}$ is the price (in the firm's local currency) charged for sales to market $\boldsymbol{i} ; \boldsymbol{q}_{\boldsymbol{i}}$ is the quantity sold in market $\boldsymbol{i}$; and $\boldsymbol{C}\left[\mathrm{]}\right.$ is total cost as a function of total output $\left(\Sigma q_{i}\right)$, the price of domestic 
inputs $\left(\boldsymbol{p d} \boldsymbol{d}_{\boldsymbol{1}}\right)$, and the price of imported inputs in terms of the firm's local currency $\left(\boldsymbol{p m} \boldsymbol{m}_{\boldsymbol{1}}\right){ }^{4}$

Demand in each market (equation (2)) is a function of the price of the good relative to the average price of competing goods in the buyer's market. The exchange rate, $\boldsymbol{e}_{\boldsymbol{i}}$, is defined as the number of units of country $\boldsymbol{i}$ currency for each unit of country $\boldsymbol{l}$ currency. The competitors' price in terms of country $\boldsymbol{i}$ currency is $\boldsymbol{p} \boldsymbol{c}_{\boldsymbol{i}}$. In principle, the competitors' price includes the prices of domestic producers in the destination market as well as the prices of third-country exporters to that market. This demand curve reflects not only consumer behavior in the destination market, but also market features such as the degree of concentration and the exporter's market share. Consumer demand, in turn, may depend on the state of the business cycle or other conditions in the destination market.

$$
q_{i}=Q_{i}\left[\frac{e_{i} p_{i}}{p c_{i}}, \text { other factors in country } i\right] \quad i=1, \ldots ., n \quad \frac{\partial q_{i}}{\partial\left[\frac{e_{i} p_{i}}{p c_{i}}\right]}<0
$$

Maximization of (1) subject to (2) and taking a first-order logarithmic approximation yields the following relationship for the price charged by the exporting firm (expressed in the firm's local currency):

$$
\ln \left(p_{i}\right)=\mu_{i}+\beta_{i} \ln (M C)+\left(1-\beta_{i}\right) \ln \left(\frac{p c_{i}}{e_{i}}\right) \text {, s.t. } p_{i} \geq M C
$$

\footnotetext{
${ }^{3}$ This model is used in Gagnon and Knetter (1995) and derived more formally in Knetter (1995).

${ }^{4}$ An appreciation of the exporter's currency may reduce the price of imported intermediates and, thus, reduce the costs borne by the exporting firm. Gron and Swenson (2000) show that this is one reason that pass-through may be less than one. (Our empirical work below does not control for imported intermediate inputs, given the limited availability of such data.)
} 
where $\mu_{i}$ and $\beta_{i}$ are destination-specific coefficients that are functions of the demand curve in each market, and $\boldsymbol{M C}$ is marginal cost expressed in the exporter's local currency. Differences in $\mu_{\boldsymbol{i}}$ (for $\left.\boldsymbol{i}=1, \ldots, n\right)$ reflect differences in markups across markets that are not related to prices and costs, whereas differences in $\beta_{i}$ determine the responsiveness of markups to changes in marginal cost and competitors' prices in each market. A key feature of equation (3) is the restriction that the coefficients on marginal cost and competitors' prices sum to one. This homogeneity restriction is necessary for long-run monetary neutrality.

For most plausible demand curves, $\boldsymbol{\beta}$ is expected to lie between 0 and 1 . As such, the constant markup model is a special case of equation (3) in which $\beta=1$ and $\boldsymbol{\mu}$ is the markup over marginal cost. ${ }^{5}$ For $\beta<1$, the markup of price over marginal cost depends on both $\mu$ and $\beta$. In this case, producers find it optimal to adjust their markups in response to competitors' prices, and they do not fully pass-through changes in marginal cost because of the competitive disadvantage that implies. In general, as $\beta$ declines, exporting firms find it more difficult to pass through shifts in their marginal costs and are increasingly faced with the choice of matching their competitors' price or exiting the market.

Note that the price of imports in terms of country $i$ 's currency is just the export price in terms of country $l$ 's currency multiplied by the exchange rate. Thus, equation (3) can be

\footnotetext{
${ }^{5}$ The familiar constant markup model is derived by setting $\beta=1$ and using the approximation $\ln (1+\boldsymbol{\mu})=\boldsymbol{\mu}$, yielding $\boldsymbol{p}=(\boldsymbol{1}+\boldsymbol{\mu}) \boldsymbol{M C}$. When marginal cost equals average cost, then $\boldsymbol{\mu}$ is the profit margin. 
translated into an equation for country $\boldsymbol{i}$ 's import prices by adding the logarithm of the exchange rate to both sides:

$$
\ln \left(e_{i} p_{i}\right)=\mu_{i}+\beta_{i} \ln \left(e_{i} M C\right)+\left(1-\beta_{i}\right) \ln \left(p c_{i}\right)
$$

where all three variables (the price of the good, the firm's marginal cost, and the competitor's price) are now expressed in terms of the currency of country $\boldsymbol{i}$.

Differentiating equations (3) and (4) yields the following expressions for the "direct effect" of changes in the exchange rate on export prices (equation (3')) and import prices (equation $\left.\left(4^{\prime}\right)\right)^{6}$

$$
\begin{aligned}
& \partial \ln \left(p_{i}\right) / \partial \ln \left(e_{i}\right)=\boldsymbol{\beta}_{\boldsymbol{i}}-1 \\
& \partial \ln \left(e_{i} p_{i}\right) / \partial \ln \left(e_{i}\right)=\boldsymbol{\beta}_{\boldsymbol{i}}
\end{aligned}
$$

The exchange rate's direct effect on the price of exports (denominated in the exporter's local currency) is $\beta_{\boldsymbol{i}}-1$, whereas the direct effect of the same exchange rate move on the price of imports (in terms of the importing-country's currency) is $\boldsymbol{\beta}_{\boldsymbol{i}}$. We thus equate $\boldsymbol{\beta}_{\boldsymbol{i}}$ with passthrough to import prices and $\beta_{i}-1$ with pass-through to export prices.

With these observations in hand, we can sketch out the implications of various values of $\beta_{i}$ for pricing behavior:

${ }^{6}$ These derivatives are obtained when other variables and the coefficients do not respond to moves in the exchange rate. 
- If $\boldsymbol{\beta}_{\boldsymbol{i}}=1$, pass-through to import prices is complete. Correspondingly, exporters do not adjust the price in their local currency in response to an exchange rate move.

- If $\boldsymbol{\beta}_{\boldsymbol{i}}=0$, the import price (in the importing country's currency) is unaffected by the exchange rate move, and the exporters' local-currency price moves one-for-one with the exchange rate.

- As an intermediate case, if $\boldsymbol{\beta}_{\boldsymbol{i}}=0.3$, a one percent depreciation of the importing country's currency would raise import prices 0.3 percent and reduce the local-currency price of exports 0.7 percent.

Notably, equations (3) and (4) describe bilateral trade prices between country 1 and country $\boldsymbol{i}$. It is a straight-forward exercise, however, to aggregate these equations across trading partners to find expressions for the multilateral export price of country 1 and the multilateral import price of country $\boldsymbol{i}$. Indeed, aggregate versions of these equations are the basis for the empirical work that is reported in the following sections of this paper.

We finally observe that $\beta$ and $\mu$ are not deep, constant parameters of the economic model but may vary over time in response to changes in the frequency and types of economic shocks and the broad features of the economic environment. Specifically, Feenstra, Gagnon, and Knetter (1996) derive a nonlinear relationship between $\boldsymbol{\beta}$ and the aggregate market share of exporters from a given source country. Gust, Leduc, and Vigfusson (2006) show that, in a world with strategic complementarity among goods, an improvement in the competitive position of foreign exporters relative to domestic firms (owing, for example, to reduced tariff barriers or lower transportation costs) may increase the willingness of foreign exporters to vary the homecurrency price of their exports in response to moves in the exchange rate. Taylor (2000) suggests that the "perceived persistence" of economic shocks may affect the extent of passthrough as well. 


\section{Empirical Strategy and Key Data}

\subsection{Empirical specification}

The baseline model that we use to examine the responsiveness of export prices to changes in the exchange rate is an empirical analog of equation (3). We take export prices denominated in the exporter's currency as the dependent variable $\left(\mathrm{PX}_{\mathrm{t}}\right)$. The first explanatory variable, $\mathrm{E}_{\mathrm{t}}$, is the exporting country's nominal effective exchange rate (a trade-weighted average against the currencies of 35 countries, with a rise indicating a depreciation of the exporter's currency). ${ }^{7}$ The second explanatory variable, $\mathrm{PF}_{\mathrm{t}}$, is the PPI of the exporting-country, which serves as a proxy for the marginal costs borne by exporting firms. ${ }^{8}$ This yields the following empirical model:

$$
\Delta \ln \left(\mathrm{PX}_{\mathrm{t}}\right)=\mu+\delta(\mathrm{L}) \Delta \ln \left(\mathrm{E}_{\mathrm{t}}\right)+\beta(\mathrm{L}) \Delta \ln \left(\mathrm{PF}_{\mathrm{t}}\right)+\mathrm{u}_{\mathrm{t}}
$$

where $\delta()$ and $\beta()$ are polynomials in L, the lag operator. Accordingly, the value of $\delta(1)$ is the total exchange rate sensitivity of export prices (denominated in the exporter's currency), and $\beta(1)$ is the total sensitivity of export prices to shifts in the exporting country's domestic price level. Both of these coefficients are expected to be positive.

Relative to equation (3) above, equation (5) does not include competitors' prices in export markets. We controlled for these prices in a variety of preliminary regressions, and the

\footnotetext{
${ }^{7}$ The number of countries included in the exchange rate calculation is reduced to the extent that the number of countries in a regional aggregate exceeds one. For example, the regional aggregate for the Asian NIEs includes four countries, so the exchange rate in this case is a trade-weighted average against the currencies of 32 other countries.

${ }^{8}$ While the PPI is probably more closely related to firms' average costs than to firms' marginal costs, no clearly superior proxy for marginal costs is available. That said, we experimented with specifications that used economy-wide unit labor costs as an alternative proxy. We found that the estimated exchange rate sensitivities of export prices were similar to those we obtain with the PPI.
} 
estimated coefficients were almost uniformly insignificant. For this reason, we have excluded this variable from our specification. The model is estimated using quarterly data. We find that exchange rate pass-through to export prices tends to occur quite rapidly, with the effects fully captured by the contemporaneous change in the exchange rate and a one-quarter lag. The lag structure for $\mathrm{PF}_{\mathrm{t}}$ is identical.

Two other comments about equation (5) are useful. First, note that in the analytical framework outlined above, equation (3) implies that $\delta(1)$ equals $(1-\beta(1)) .^{9}$ This, in turn, suggests that $\delta(1)$ and $\beta(1)$ should sum to unity--a relationship that arises as a result of the homogeneity restriction that is imposed on equation (3). We will explicitly test this implication of the homogeneity restriction in our empirical work below. Second, another feature of the analytical framework is that the parameter $\beta_{\mathrm{i}}$ governs the extent of exchange rate pass-through into country i's import prices (shown in equation (4)) as well as the extent to which shifts in marginal costs are reflected in country 1 's export prices (shown in equation (3)). In other words, the passthrough of exchange rate changes into import prices (expressed in the importing country's currency) is posited to be equivalent to the pass-through of cost shocks into export prices (expressed in the exporting country's currency). To the extent that this is the case empirically, the estimated coefficient on $\mathrm{PF}_{\mathrm{t}}$, our proxy for marginal cost, will provide an alternative metric for assessing exchange rate pass-through to import prices.

\footnotetext{
${ }^{9}$ In equation (3), the coefficient on the exchange rate is $-(1-\beta)$. In equation (5), however, the definition of the exchange rate has been inverted so that an increase in the index is a depreciation of the exporter's currency, and this yields the relationship between $\delta$ and $\beta$ indicated in the text. 
Finally, we note that the estimated coefficient $\delta(1)$ reports the average relationship between export prices and the exchange rate across the range of shocks that hit the exchange rate during the sample period. In this respect, our empirical work is distinctly reduced-form in flavor. As further indication of the reduced form nature of our work, we also note that shocks to export prices could at times feed back onto the exchange rate; this may particularly be an issue for a commodity-exporting country such as Canada. We would typically address this endogeneity issue by using instrumental variables, but the availability of plausible instruments for the exchange rate is limited and continuing the search for such instruments is beyond the scope of our paper.

\subsection{Export price data and the profit margins of foreign exporters}

In estimating this model, we use two complementary sources of data. First, with an eye toward examining the pricing behavior of firms exporting to the United States, we employ Bureau of Labor Statistics (BLS) data on bilateral U.S. import prices by region. These bilateral data are available in sufficiently long time series for the European Union, Japan, Canada, and the

Asian NIEs. ${ }^{10}$ Second, we also study the multilateral export price data for goods exported from these countries--that is, the prices charged to all destinations; these data are drawn from country sources. Throughout this paper, we express the BLS data in terms of the exporting country's currency in order to be comparable with the multilateral export price data. Our examination

\footnotetext{
${ }^{10}$ The Asian NIEs include Hong Kong, Korea, Singapore, and Taiwan. 
focuses on the prices of exported goods, including raw materials. ${ }^{11}$ We do not consider the behavior of services prices.

The BLS data on prices charged in the U.S. market may behave differently than foreign multilateral export price data for several reasons. First, the quality or product composition of exports to the United States may differ from that to other destinations. Second, the pricing behavior of exporting firms may differ across export destinations, i.e., exporters may engage in price discrimination across their various export destinations. Third, differences in the methodology used to construct the price indexes may also contribute to deviations between them. ${ }^{12}$ These possibilities are considered in more detail below.

Despite these potential sources of divergence, Figures 1 and 2 show that the foreign export price data (the dotted lines) and the BLS data (the dashed lines) generally trend together over time. In particular, following the dollar's peak in early 2002, both measures posted declines for the EU and Japan, although the prices charged in the United States fell by more in both cases.

\footnotetext{
${ }^{11}$ The multilateral export price series that we use for the United Kingdom excludes oil. Canada-the other major oil-exporting country that we study--does not publish a measure of export prices that excludes oil, so we use the price index for total exports. For Germany, multilateral export prices prior to 1991 are for West Germany only. Finally, multilateral export price data for the aggregate European Union, Germany, and the United Kingdom include intra-EU trade.

${ }^{12}$ The IMF Balance of Payments Manual (1993), which outlines international standards for balance of payments statistics, indicates that "exports and imports of goods [should be] recorded at market values at points of uniform valuation, that is, the customs frontiers of exporting economies." Consistent with this statement, bilateral U.S. import prices have the objective of capturing the price of the good at the port of export (BLS, 1997), and foreign multilateral export prices presumably have a similar objective. As such, these measures should be comparable conceptually. Nevertheless, across the array of countries that we study, there are inevitable differences in the methodology used to collect and compile trade price data. For example, the Canadian export price index is constructed using data from the producer price index, rather than independently sampled export prices (Statistics Canada, 2006). In addition, for most of the countries that we study, the export price data are quality-adjusted price indexes, but two notable exceptions are the aggregate data for the European Union (from Eurostat) and the data for Hong Kong, which in both cases are unit values. 
For Canada, the U.S. dollar did not decline in earnest against the Canadian dollar until early 2003, but Canadian export prices and the BLS measure both declined on balance thereafter. (As 85 percent of Canadian exports go to the United States, the two measures move very closely together.) For the Asian NIEs, multilateral export prices climbed in 2004, but the BLS measure of prices charged in the U.S. market continued to drift down. In general, the BLS data showed marked declines following the dollar's peak in early 2002, while multilateral export prices for these economies fell less or posted modest increases.

Figures 1 and 2 also display measures of economy-wide unit labor costs for these countries. To the extent that such measures accurately reflect the costs borne by foreign exporters, movements in the profit margins of exporting firms may be proxied by changes in export prices relative to changes in unit labor costs. ${ }^{13}$ Given this proxy for profit margins, the BLS data suggest that foreign margins in the U.S. market recorded notable declines following the dollar's peak in early 2002 (see Table 1). However, similar calculations using multilateral export prices indicate that exporting firms in Japan, Canada, and East Asia eked out gains in their margins from 2002:Q1 through 2004:Q4, with a moderation in unit labor costs helping offset soft or declining multilateral export prices. The European Union is the one region for which multilateral profit margins registered a decline.

${ }^{13}$ This proxy for profit margins is subject to some caveats. First, we use economy-wide unit labor costs because data for the export sector alone are not available. As such, this proxy will be informative only if the unit labor costs of exporting firms move broadly in tandem with aggregate unit labor costs. Second, by relying on unit labor cost data, this proxy does not directly capture moves in the costs of capital or materials. 
This configuration of results suggests that foreign exporters saw their margins compressed in the United States as the dollar depreciated, but they were able to offset this in other markets--likely in markets in which their currencies remained more competitive. (Of course, exporters from the euro area had little scope to pursue this strategy, as the euro moved up against essentially all currencies.)

While our proxy for profit margins on exports to the United States narrowed after early 2002, we do not have sufficient evidence to conclude that the profit margins that prevailed in late 2004 were "too narrow"--profits several years earlier might have been unusually high. As just one case in point, the first three columns of Table 1 compare movements in export prices and unit labor costs over the preceding period, 1995-2002. This exercise suggests that profit margins

on exports to the United States posted a dramatic run-up between the dollar's trough in the spring of 1995 and the dollar's peak in early 2002. Indeed, despite the subsequent unwinding, profit margins for Japanese exporters to the United States in late 2004 remained well above those that prevailed in the second quarter of 1995, while profit margins for European Union, Canadian, and Asian NIE exporters were either up some or little changed on balance. On a multilateral basis, the profit margins of exporters from these economies were all up in late 2004 relative to the spring of 1995, albeit to varying degrees.

\section{Regression Results}

\subsection{Benchmark model}

Table 2 reports the results obtained when we estimate equation (5). Foreign multilateral export prices denominated in the exporter's currency are regressed on the exporting country's 
nominal effective exchange rate (NEER) and PPI. Our regressions begin in the early 1980s, except for the aggregate EU where data do not become available until 1989. As noted above, for Canada, PPI data are used explicitly in compiling the export price index, creating a high correlation between export prices and the PPI by construction (Statistics Canada, 2006). For this reason, we use the Canadian CPI as our proxy for the country's domestic prices.

As shown in Table 2, the response of foreign multilateral export prices to movements in the NEER is statistically significant, but the degree of sensitivity varies across countries and regions. Specifically, the estimated coefficients for the European Union as a whole, the United Kingdom, Canada, and the Asian NIEs are all in the neighborhood of 0.3, while the coefficient for Japan is near 0.5 . These results suggest that a 10 percent nominal effective depreciation of the EU currencies, the Canadian dollar, or the Asian NIE currencies would raise the price of exports from these regions about 3 percent (in terms of their own currencies), whereas a similar decline in the nominal effective yen would boost the yen price of Japanese exports 5 percent. (Equivalently, in terms of the currencies of importing countries, European, Canadian, and Asian NIE export prices would decline 7 percent, and Japanese export prices would decline 5 percent.) In contrast, German domestic-currency export prices have shown surprisingly little responsiveness to the NEER, implying almost complete pass-through in terms of importing countries' currencies. The results for Germany indicate that the country's export prices move closely with the domestic price level. The responsiveness of U.S. export prices to the NEER, shown in the last line of Table 2, is somewhat higher than that for Germany but nevertheless is 
also quite low. These results, however, do not rule out the possibility that the exchange rate may influence U.S. or German export prices indirectly through effects on the PPI.

As mentioned above, the homogeneity restriction in equation (3) implies that the coefficients on the exchange rate and the price level in the exporting country should sum to one. Hypothesis tests--reported in column (8)--indicate that the homogeneity condition is rejected for Germany and the United Kingdom but is not rejected for the aggregate EU, Japan, Canada, the Asian NIEs and the United States.

To examine the robustness of these results, the upper panel of Table 3 shows estimates obtained when the NEER is replaced by the nominal bilateral exchange rate against the dollar. Two key results emerge from this specification. First, in most cases, foreign multilateral export prices actually appear to be about as sensitive to the dollar as they are to the NEER, and the regression coefficients are estimated with somewhat greater precision. Second, and even more striking, the $\mathrm{R}^{2}$ statistics for this model are as high as--or higher than--those for the baseline model. The homogeneity condition, however, is rejected in every case except the aggregate EU. The lower panel of Table 3 reports the results obtained when foreign multilateral export prices (denominated in the exporter's currency) are regressed on a streamlined model that includes the nominal bilateral dollar as the only explanatory variable. In this case, the exchange rate sensitivities remain near those shown in Table 2, and--with the notable exception of Germany--the $\mathrm{R}^{2}$ statistics are also broadly similar. Taken together, the results in Table 3 underscore the importance of the dollar and, perhaps, the centrality of the U.S. market in influencing the evolution of the prices of traded goods internationally. 
A question that emerges from our work is why the exchange rate sensitivity of export prices is lower in the United States and Germany than in the other countries. Certainly, both the United States and Germany export sophisticated capital goods, which may give them pricing power within certain market niches. This explanation should not be overstated, however, since Japan and the Asian NIEs (at least to some extent) also export these kinds of products. We conjecture that for the United States an additional factor is the very large home market, which may limit firms' incentives to deviate from the prevailing domestic price. German exporters might have experienced similar effects, given both the large domestic market and the deepening of European integration that occurred during the sample period. These hypotheses, however, are tentative and only suggest directions for future work. For example, a careful exploration of the dis-aggregated trade data may help uncover further evidence.

\subsection{The exchange rate sensitivity of export prices charged in the U.S. market}

The previous regressions have focused on multilateral export prices, i.e., the prices of exports to all markets. In the upper panel of Table 4, we turn to the related issue of whether the prices charged on exports to the United States manifest behavior that differs systematically from the prices charged to other destinations. Because foreign countries do not publish price indexes for their bilateral exports, we use as a proxy--and as the dependent variable in our regressions-the BLS indexes of bilateral U.S. import prices, which we translate into the exporter's currency. These BLS indexes are available in sufficient time series for the European Union, Japan, Canada, and the Asian NIEs. The explanatory variables in these regressions are the nominal bilateral dollar exchange rate and the exporting country's PPI. (The BLS data begin only in 1991; for 
purposes of comparison, the lower panel of Table 4 reports the results obtained when our benchmark model--equation (5)--is estimated with a sample that also begins in 1991.) As shown in Figure 3, in recent years, exports to the United States have accounted for about 10 percent of exports from Germany and from the EU as a whole, about 15 percent of exports from the United Kingdom, about 20 percent of exports from Japan and the Asian NIEs, and about 85 percent of Canada's exports.

Without exception, the estimated coefficients for the export prices charged in the U.S. market are more sensitive to the exchange rate than is the case for multilateral export prices. As displayed in the upper panel, estimates for all four regions suggest that over the last decade or so, a 10 percent appreciation of the exporter's currency against the dollar has been associated with a 7 to 8 percent decline in export prices charged in the U.S. market (denominated in the currency of the exporting country). ${ }^{14}$ In contrast, as shown in the lower panel, for these same four regions, a 10 percent appreciation of their currencies since 1991 would result in a decline in their multilateral export prices ranging from 3 percent to $5 \frac{1}{2}$ percent. $^{15}$

The greater exchange rate sensitivity of export prices charged in the U.S. market is equivalent to showing that import price pass-through is lower in the United States than in other economies on average, thus confirming results elsewhere in the literature. ${ }^{16}$ Consistent with

\footnotetext{
${ }^{14}$ Equivalently, the results suggest that a 10 percent appreciation of these currencies against the dollar would raise the price of U.S. imports from these trading partners about 2 to 3 percent.

${ }^{15}$ For several of these economies, the sensitivity of multilateral export prices to the exchange rate increased markedly in the 1991 to 2004 period, relative to the longer samples reported in Table 2. We examine this issue in more detail in the following section.

${ }^{16}$ See, for example, Campa and Goldberg (2002, 2005), Ihrig, Marazzi, and Rothenberg (2006), and Sekine (2006).
} 
Dornbusch (1987), we would explain the greater willingness of foreign exporters to vary their margins when selling into the U.S. market as reflecting the large size of the U.S. marketplace and the resulting fact that there are competing U.S. producers--or producers from countries whose currencies are closely linked to the dollar--for most goods exported to the United States. In addition, as suggested by Campa and Goldberg (2005), the relative macroeconomic stability that has prevailed in the United States over the last couple of decades has likely played some role as well. ${ }^{17}$ Finally, as shown in Figure 3, in every country except Japan, finished goods (i.e., autos, capital goods, and consumer goods) account for a somewhat larger share of exports to the United States than is the case for multilateral exports. Evidence suggests that exchange rate passthrough to the import prices of finished goods is lower than pass-through for more commodityintensive products. ${ }^{18,19}$

As noted above, an implication of our analytical framework is that the coefficient $\beta$ reflects both the extent of exchange rate pass-through to country i's import prices and the extent to which shifts in marginal cost are reflected in export prices. As such, the estimated coefficient on foreign prices, which proxy for marginal cost, should provide an additional window into

\footnotetext{
${ }^{17}$ In a careful study of the determinants of import price pass-through for a panel of OECD countries, Campa and Goldberg find that pass-through is positively related to inflation, money growth, and nominal exchange rate volatility.

${ }^{18}$ For example, we find that over the past decade, a 10 percent depreciation of the dollar has typically raised U.S. finished-goods import prices 3 percentage points less than has been the case for other U.S. non-oil import prices. (Footnote 24 provides details regarding the regression specification used to obtain these results.)

${ }^{19}$ Another explanation for the higher exchange rate sensitivity of export prices charged in the U.S. market--which cannot be completely ruled out--is that there are differences in the construction of U.S. bilateral import prices and foreign multilateral export prices that tend to be manifest in differing sensitivities to the exchange rate.
} 
import price pass-through. For the bilateral export price results shown in the upper panel of Table 4, the estimated coefficients on the exporting country's prices are generally quite low. Notably, these coefficients are much lower than their multilateral counterparts in the lower panel, again suggesting that import price pass-through in the U.S. market is more muted than in other markets on average. Finally, it is worth noting that for every specification in the upper panel of Table 4, we fail to reject the homogeneity condition that requires the coefficients on the exchange rate and the exporting country's price level to sum to unity.

\subsection{Rolling regressions}

This section employs the baseline specification outlined in equation (5) to conduct rolling regressions for a number of countries/regions where sufficient data are available. The rolling regressions use a ten-year window and show how the domestic-currency price of multilateral exports responds to movements in the NEER. The goal is to assess whether any of these countries have seen their export prices (denominated in their local currencies) become more sensitive to exchange rate movements, which might be seen as a counterpart to the recent decline in import price pass-through observed in the United States and several other countries. As a robustness check, we also report results obtained when five-year rolling windows are used; although these estimates are somewhat volatile and should be interpreted with caution, they nevertheless provide a useful alternative look at the data.

The results for Germany, which are reported in the top panel of Figure 4, suggest that the exchange rate sensitivity of German export prices has been low and remarkably stable over time, with neither German re-unification in 1990 nor the introduction of the euro in 1999 leaving a 
perceptible imprint on the estimates. ${ }^{20}$ The exchange rate sensitivity of Japanese export prices is markedly higher than for Germany, with the estimates obtained using a ten-year window cycling around 0.5 through most of our sample period and drifting up only slightly of late. The five-year samples, however, show a more striking upward move in recent years.

For the United Kingdom, the estimates obtained using a ten-year window manifest an upward trend through much of the sample period, but this is rapidly reversed in early 2003 . We conjecture that the sharp decline in the exchange rate sensitivity of UK export prices at that time reflects the fact that the late-1992 ERM crisis had finally rolled out of the sample. Consistent with this hypothesis, the estimates using a five-year window move down sharply in early 1998. In the most recent five-year and ten-year samples, however, the responsiveness of UK export prices to the exchange rate has again picked up.

For Canada, ten-year rolling windows show the exchange rate sensitivity of export prices (Figure 5) stepping up from near zero for windows ending in the first half of the 1990s to roughly 0.3 to 0.4 in most subsequent ten-year samples. We hypothesize that the timing of this upward move in the sensitivity of export prices is linked to NAFTA and the deepening economic integration with the United States. ${ }^{21,22}$ The results using five-year windows amplify this

\footnotetext{
${ }^{20}$ Notably, at the time of re-unification, exports from East Germany were only a fraction of those from West Germany. (The IMF's Direction of Trade Statistics Yearbook (1993) reports that East German exports in 1989 were just $\$ 22.2$ billion, compared with West German exports that year of \$341.2 billion.)

${ }^{21}$ The fact that the Canadian export price index is constructed using trade-weighted producer prices bears on the interpretation of these results. In particular, due to this feature of the data, evidence of increased responsiveness of Canadian export prices may result from a change in the price-setting behavior of exporters, but it may also reflect an increasing convergence in the behavior of domestic prices and export prices or a rising share of exports in domestic production. That said, NAFTA and increased integration with the United States might reasonably be thought to have contributed to any or all of these developments.
} 
observation. The exchange rate sensitivity of Canadian export prices seems to have moved inversely with the strength of the U.S. dollar--rising in the mid-1990s as the dollar weakened, falling through the late 1990s and early this decade as the dollar strengthened, and rising over the past couple of years as the dollar again depreciated. Canadian exporters, given their dependence on demand from the United States and the deepening integration between the two countries, have apparently aimed to protect (or bolster) their share of the U.S. market, cutting their prices in the United States when the U.S. dollar appreciates but not fully hiking their U.S. prices when the greenback falls.

For the Asian NIEs, the exchange rate sensitivity of export prices estimated using tenyear samples jumped from 0.1 to 0.5 in the late 1990 s, about the time of the Asian financial crisis. In subsequent years, this sensitivity has increased further, to around 0.7. The results obtained using five-year samples shed important light on what is driving these estimates. Specifically, the exchange rate sensitivity of Asian NIE export prices rose sharply during the time of the Asian financial crisis, suggesting that exporting firms maintained their foreigncurrency prices even as exchange rates in the region depreciated sharply. Notably, however, once the period of the financial crisis rolls out of the five-year window, the estimated sensitivity of export prices declines rapidly. As such, our results indicate that the elevated exchange rate sensitivity observed in the ten-year estimates owes more to the effects of the crisis and the immediate aftermath than to subsequent events in the region.

\footnotetext{
${ }^{22}$ For example, vertical integration could heighten the sensitivity of Canadian export prices to exchange rate moves, as a decline in the U.S. dollar would lower the cost of U.S.-made inputs for Canadian exporters (in terms of their local currency) and, thus, provide increased scope for exporters to lower their Canadian-dollar price. 
Finally, the bottom panel reports the sensitivity of U.S. export prices to moves in the nominal effective dollar. When a ten-year rolling window is used, we find that this sensitivity has cycled between zero and 0.2 over the past couple of decades and is now statistically significant and near the top of that range. This result indicates that a 10 percent decline in the dollar is associated with a 2 percent rise in U.S. export prices. The estimates obtained using fiveyear samples show a bit more of an increase, to just under 0.3 , in the most recent samples.

\subsection{Andrews tests of parameter stability}

The results from our rolling regressions suggest that the coefficients in our benchmark specification have changed over the sample period. As a more formal test of this hypothesis, we follow the procedure outlined by Andrews (1993) and perform a recursive Chow test with an unknown break date. Taking the appropriate critical value from Stock and Watson (2003), we reject the null hypothesis that the coefficients in the regression model are constant over time for every country except the United States. As shown in Table 5, the identified break points tend to have intuitive explanations, reflecting the varying experiences of these countries. For example, the break points for the Asian NIEs and Japan come during the height of the Asian financial crisis, while the break point for Germany occurs at the dollar's peak in the mid-1980s. (Given the stability of our estimates for Germany, the presence of a structural break may be somewhat surprising; but the key point is that at the identified break date there is a big move in the German data relative to the customary volatility of the German data.) The break point for the United Kingdom comes somewhat after the ERM crisis, and the one for Canada comes near the loon's all-time low against the U.S. dollar early this decade. 
Table 5 also indicates which model parameters shifted significantly before and after the break dates. Confirming our earlier evidence, the responsiveness of export prices to exchange rate movements increased markedly in emerging Asia and Japan and, to a lesser extent, in Canada. We also find that the exchange rate sensitivity of U.S. export prices stepped down significantly near the time of the dollar's peak in the mid-1980s.

\subsection{How well do these results explain the recent U.S. experience?}

Figure 6 seeks to summarize the implications for U.S. import prices of the rolling regressions reported in Section 4.3. The solid line in the upper panel shows estimates of passthrough to U.S. non-oil import prices obtained from a rolling regression with ten-year windows, as in Marazzi, Sheets, and Vigfusson (2005). ${ }^{23}$ The results of this regression indicate that passthrough to U.S. import prices has fallen from about 0.6 for windows ending in the first half of the 1990s to between 0.3 and 0.4 in samples ending in the late 1990s and thereafter. The other line shows a counterfactual U.S. import price response--that is, the estimate of pass-through to U.S. import prices that is implied by weighting up our rolling multilateral export price sensitivities for Germany, Japan, the United Kingdom, Canada, and the Asian NIEs using shares of U.S. imports. (These trading partners account for nearly half of U.S. non-oil imports.)

The striking result is that this counterfactual response declines roughly in sync with the solid line, from 0.8 until the mid-1990s to below 0.6 in the latest ten-year samples. The fact that the dashed-dotted line is well above the solid line again confirms that pass-through to the United

${ }^{23}$ We regress U.S. non-oil import prices on (1) the import-weighted exchange value of the dollar against the currencies of 35 countries and (2) a similarly weighted index of foreign consumer prices. As in our other regressions, we do not include commodity prices as a separate control variable; including commodity prices would yield lower estimates of pass-through. 
States is below that to other countries on average. Consistent with this observation, recall that the evidence reported in Table 4 indicates that the relevant issue is not where goods come from but rather their destination. Using the estimates in Table 4, an import-weighted average of multilateral export price sensitivities would imply pass-through to U.S. import prices of roughly 0.2 to 0.3 , which is quite close to the estimate for all U.S. import prices. These results suggest that the decline in pass-through to U.S. import prices is not unique to the U.S. market, as this appears to be a feature of multilateral export prices sensitivities as well. What is unique to the United States is the low level of pass-through.

The lower panel of Figure 6 replicates this exercise using estimates from five-year rolling samples. As in the upper panel, the pass-through estimates obtained from U.S. import prices step down during the sample period to around 0.3. The counterfactual response of U.S. import prices (based on multilateral export price elasticities) declines steeply for samples ending until 1998, but then rises back up to between 0.6 and 0.7 for recent periods. While these results should be interpreted with caution (given the relatively short windows used in the estimation), the recent divergence between these two lines reinforces our view that foreign exporters have simply been more willing to vary their margins when selling into the U.S. market. Moreover, this difference in pricing behavior seems, if anything, to have become more pronounced in recent years.

\section{Conclusions}

This paper complements the recent literature on exchange rate pass-through to import

prices by studying the key issues from the opposite side of the transaction--that is, by examining 
the exchange rate sensitivity of export prices. In the process, we have identified several stylized facts that deepen our understanding of the contours of the pricing of globally traded goods. First, we find strong evidence--based on a range of empirical exercises and data sources--that the prices foreign exporters charge in the U.S. market are more responsive to the exchange rate than is the case for other markets on average. In this respect, the United States is special. Second, we also find evidence that the dollar plays a unique role in the determination of global traded goods prices, apparently reflecting both the prominent international role of the dollar and the centrality of the U.S. marketplace. Third, moves in the exchange rate sensitivity of export prices over time appear to have been significantly affected by country and region-specific factors, including the Asian financial crisis (for emerging Asia), deepening economic integration with the United States (for Canada), and the effects of the 1992 ERM crisis (for the United Kingdom). In our view, further exploration of these results and their attendant implications should provide fertile ground for future research. 


\section{REFERENCES}

Andrews, D., 1993, "Tests for Parameter Instability and Structural Change with Unknown Change Point," Econometrica, 61(4), 821-856.

Bureau of Labor Statistics, 1997, "International Price Indexes," Handbook of Methods, Washington, D.C.

Bussiere, M., 2004, “Non-linear Exchange Rate Pass-through?” mimeo, European Central Bank, December.

Campa, J. and L. Goldberg, 2005, "Exchange Rate Pass-through into Import Prices," Review of Economics and Statistics, 87, 679-690.

Campa, J. and L. Goldberg, 2002, "Exchange Rate Pass-through into Import Prices: A Macro or Micro Phenomenon?” NBER Working Paper 8934, May. 106.

Dornbusch, R., 1987, “Exchange Rates and Prices,” American Economic Review, 77, 93-

Feenstra, R., J. Gagnon, and M. Knetter, 1996, "Market Share and Exchange Rate PassThrough in World Automobile Trade," Journal of International Economics, 40, 187-207.

Frankel, J., D. Parsley, and S. Wei, 2005, "Slow Pass-through around the World: A New Import for Developing Countries?” NBER Working Paper 11199, March.

Gagnon, J. and M. Knetter, 1995, "Markup Adjustment and Exchange Rate Fluctuations: Evidence from Panel Data on Automobile Exports," Journal of International Money and Finance, 14, 289-310.

Goldberg, L. and C. Tille, 2004, "Vehicle Currency Use in International Trade," mimeo, Federal Reserve Bank of New York, December.

Goldberg, P. and M. Knetter, 1997, "Goods Prices and Exchange Rates: What Have We Learned?” Journal of Economic Literature, 35, 1243-1272.

Gron, A. and D. Swenson, 2000, "Cost Pass-through in the U.S. Automobile Market," The Review of Economics and Statistics, 82, 316-324.

Gust, C., S. Leduc, and R. Vigfusson, 2006, “Trade Integration, Competition, and the Decline in Exchange Rate Pass-through,” International Finance Discussion Paper 864, August. 
Ihrig, J., M. Marazzi, and A. Rothenberg, 2006, "Exchange Rate Pass-through in the G-7 Economies," International Finance Discussion Paper 851, January.

International Monetary Fund, 1993, Balance of Payments Manual, Fifth Edition, Washington, D.C.

International Monetary Fund, 1993, Direction of Trade Statistics Yearbook, Washington, D.C.

Knetter, M., 1989, "Price Discrimination by U.S. and German Exporters," The American Economic Review, 79, 198-210.

Knetter, M., 1993, "International Comparisons of Pricing-to-Market Behavior," The American Economic Review, 83, 473-486.

Knetter, M., 1995, "Pricing to Market in Response to Unobservable and Observable Shocks," International Economic Journal, 9, 1-25.

Marazzi, M., N. Sheets, and R. Vigfusson, et al., 2005, "Exchange Rate Pass-through to U.S. Import Prices: Some New Evidence,” International Finance Discussion Paper 833, April.

Olivei, G., 2002, "Exchange Rates and the Prices of Manufacturing Products Imported into the United States," New England Economic Review, First Quarter, 3-18.

Otani, A., S. Shiratsuka, and T. Shirota, 2003, "The Decline in Exchange Rate PassThrough: Evidence from Japanese Import Prices,” Monetary and Economic Studies, 21, 53-81.

Otani, A., S. Shiratsuka, and T. Shirota, 2005, "Revisiting the Decline in Exchange Rate Pass-Through: Further Evidence from Japan's Import Prices," IMES Discussion Paper Series No. 2005-E-6, July.

Sekine, T., 2006, “Time-Varying Exchange Rate Pass-through: Experiences of Some Industrial Countries,” BIS Working Papers, No. 202, March.

Statistics Canada, 2006, "Detailed Information for December 2005," International Trade Price Indexes, Record Number 2203, February.

Stock, J. and M. Watson, 2003, Introduction to Econometrics, Boston: Addison Wesley.

Taylor, J., 2000, "Low inflation, pass-through, and the pricing power of firms," European Economic Review, 44, 1389-1408. 
Figure 1

\section{European Union*}
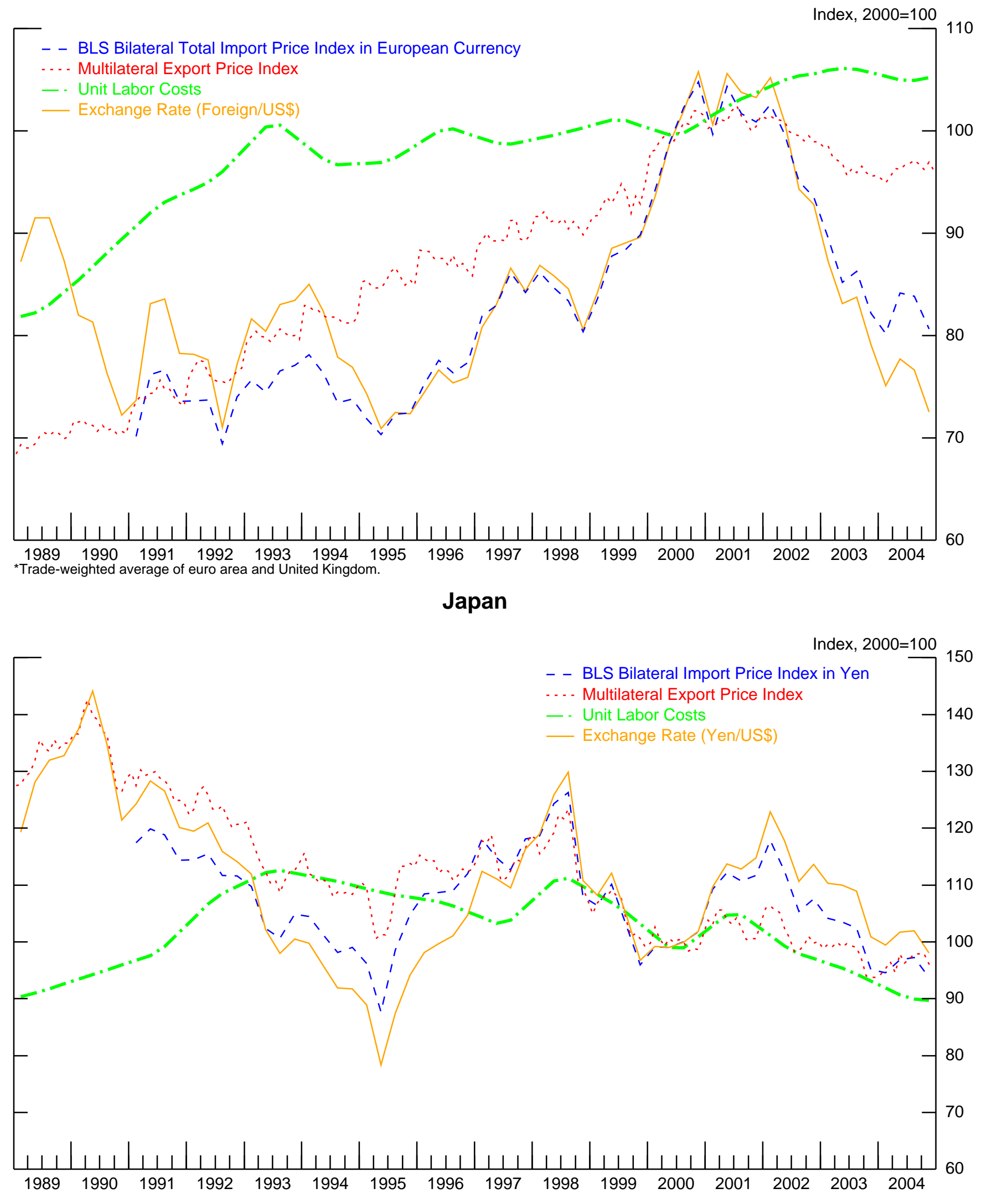
Figure 2

\section{Canada}
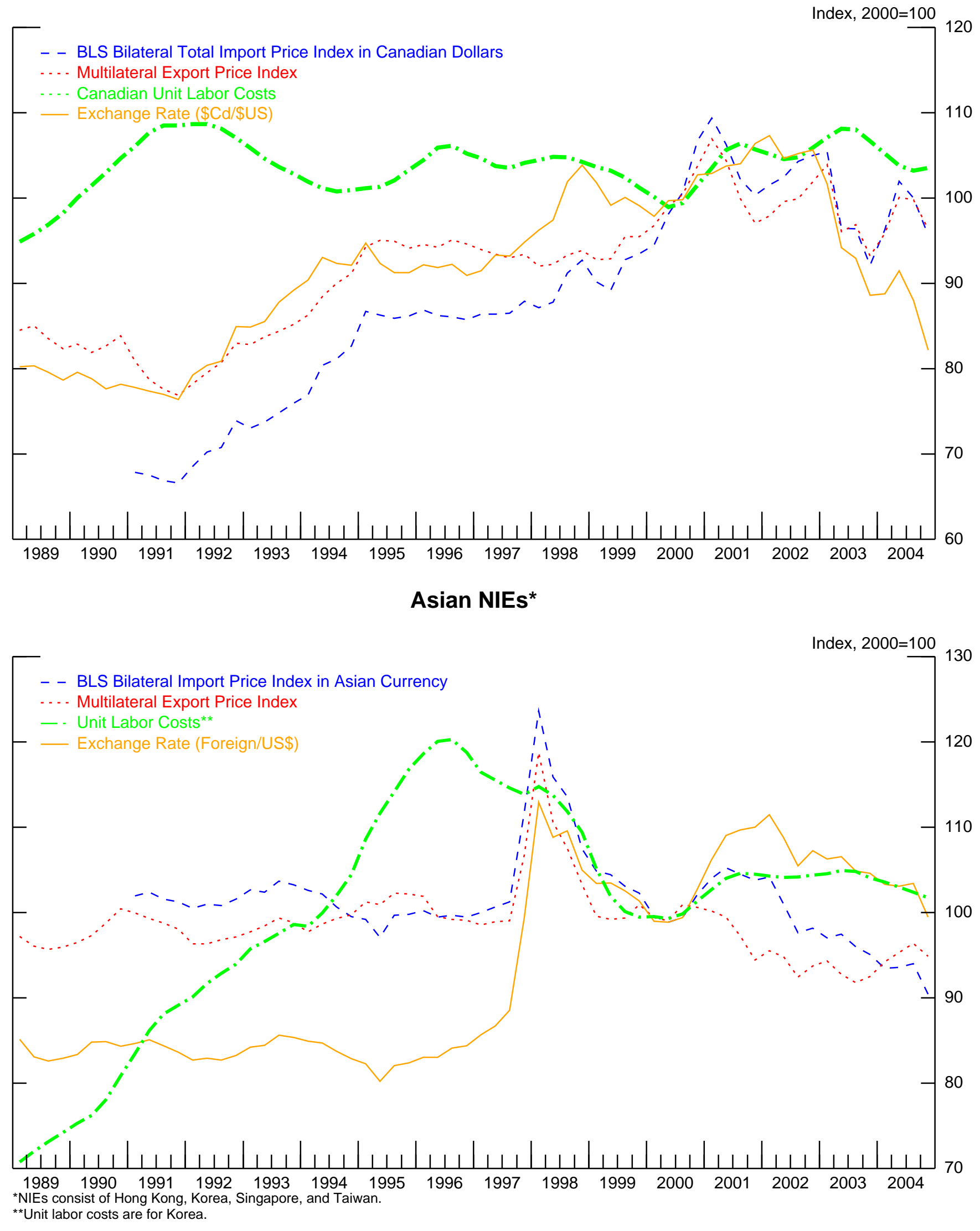
Figure 3

\section{Foreign Non-oil Export Shares}
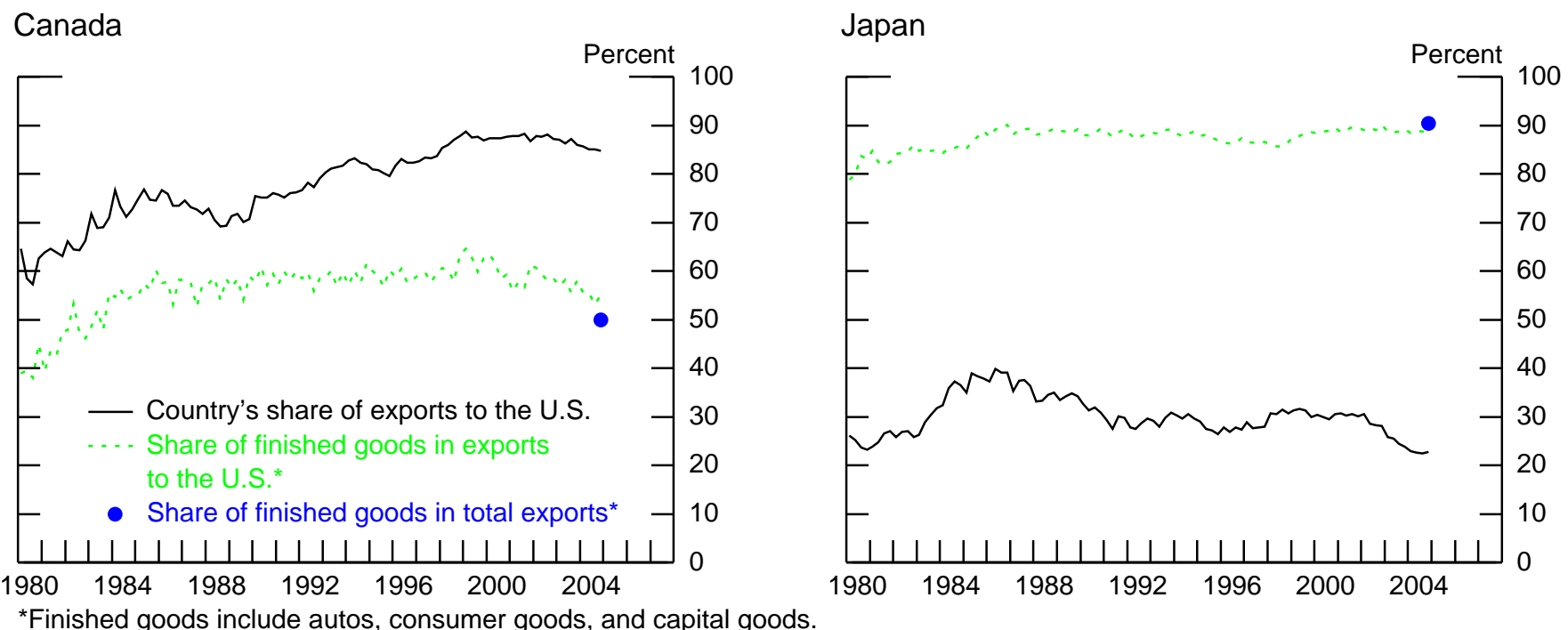

*Finished goods include autos, consumer goods, and capital goods.

Asian NIEs **

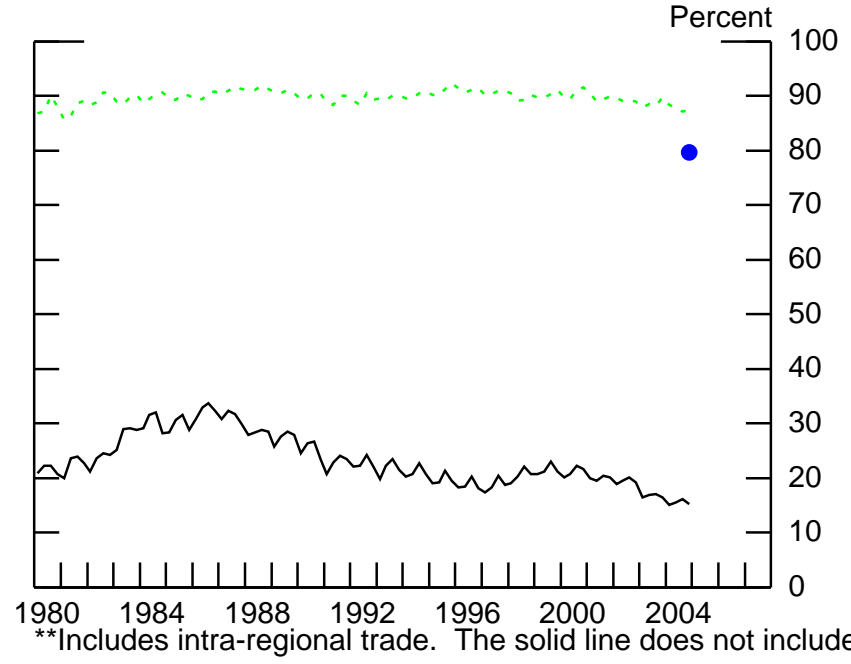

United Kingdom

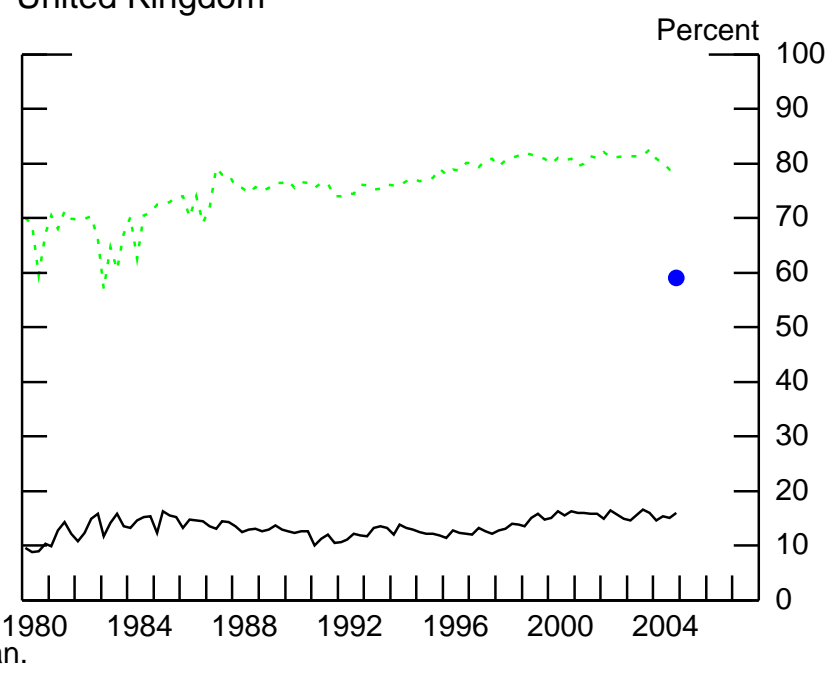

European Union

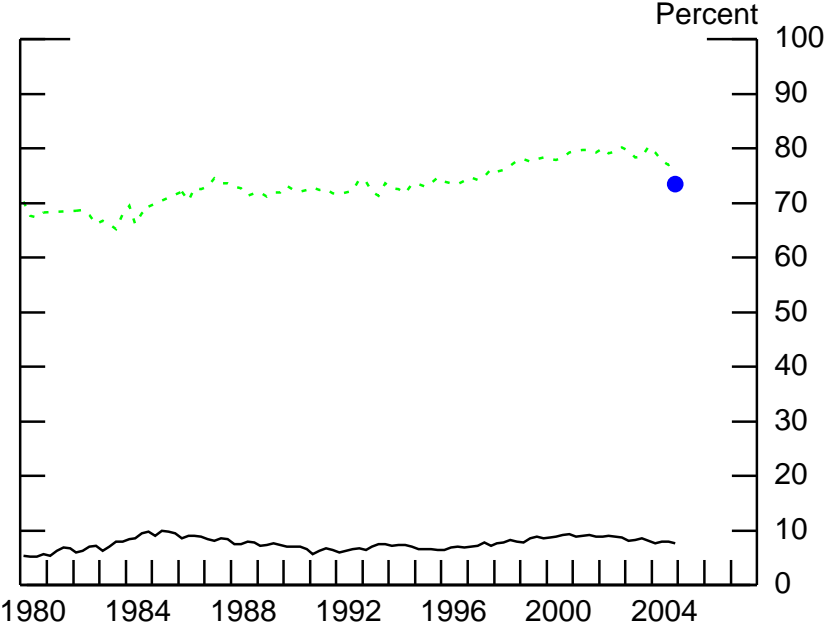

Germany

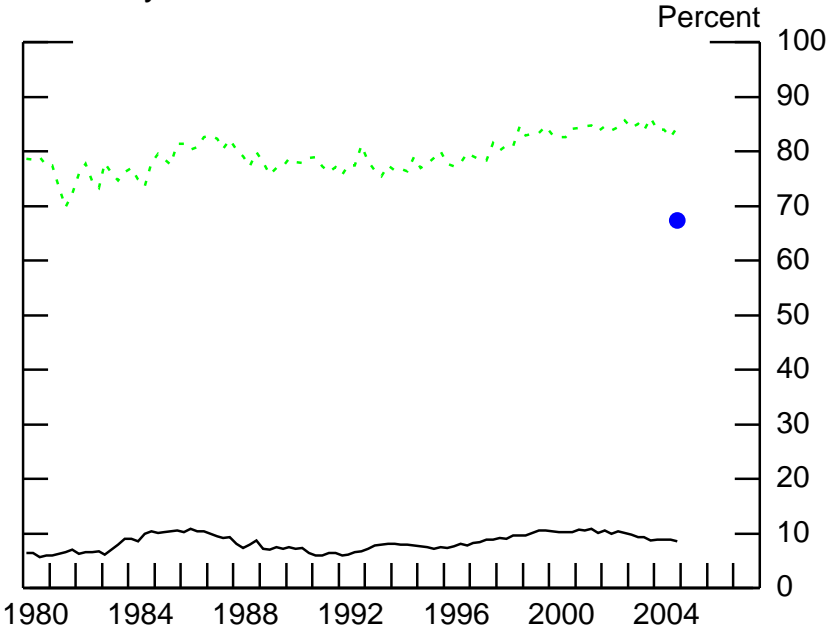


Figure 4

\section{Rolling Regression: Response of Export Prices to NEER ${ }^{*}$}

\section{Germany}

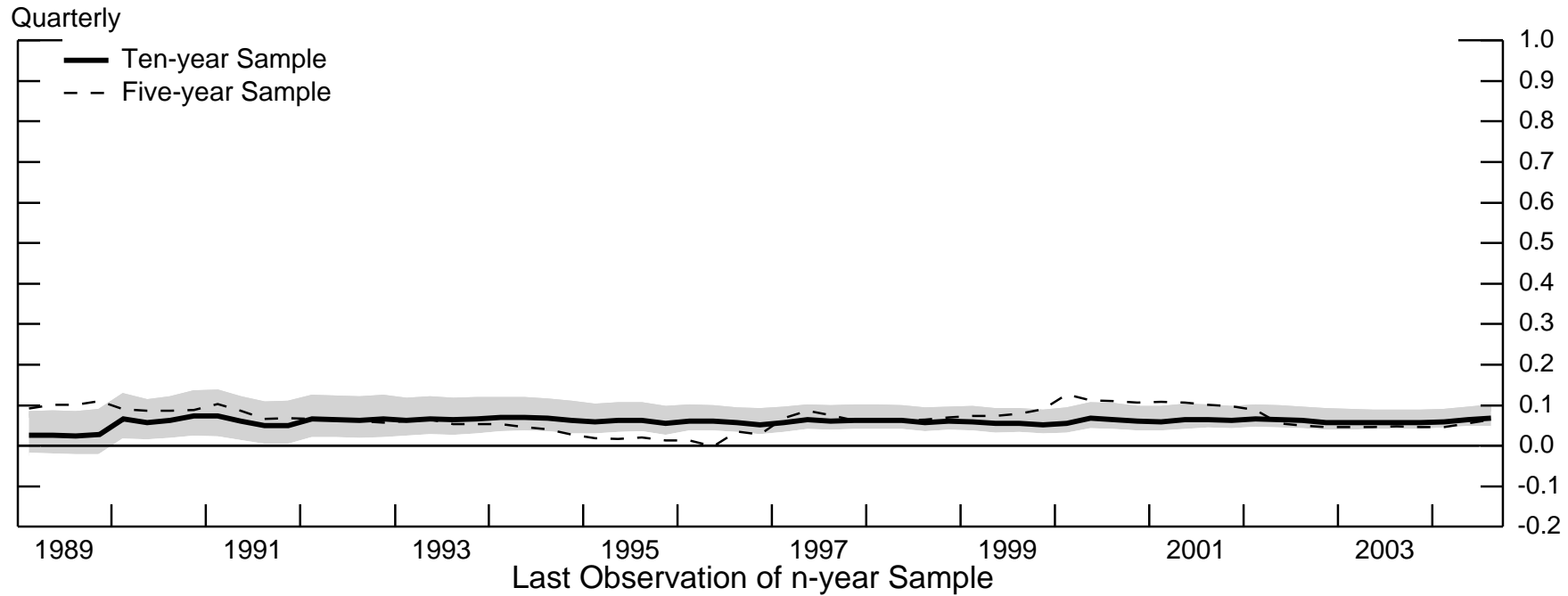

Japan

Quarterly

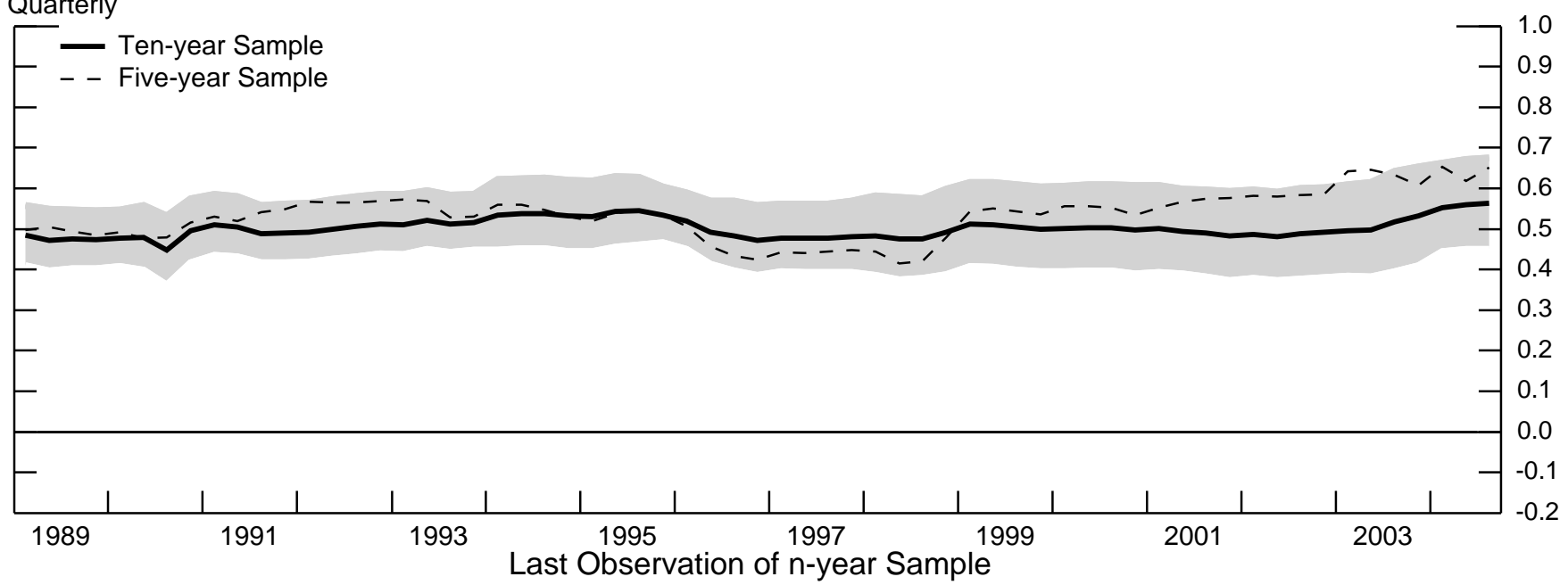

\section{United Kingdom}

Quarterly

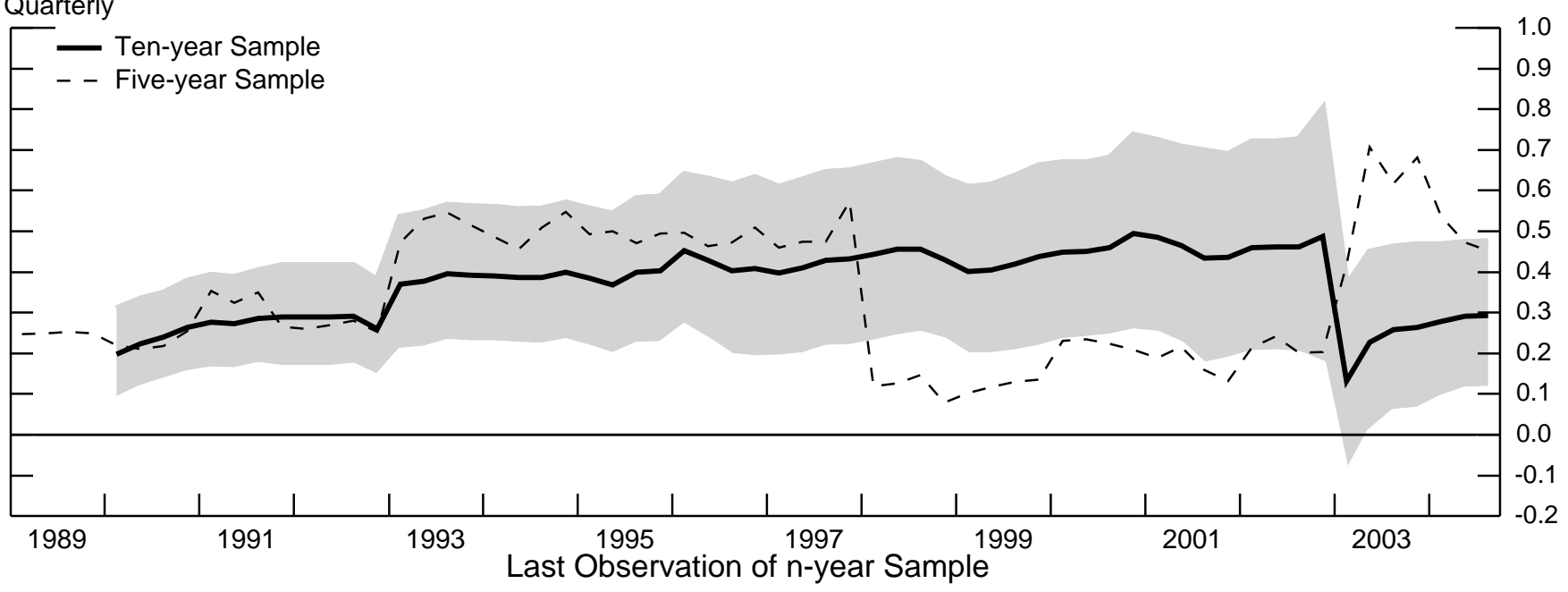

${ }^{*}$ Gray bands represent $95 \%$ confidence interval for ten-year sample. 
Figure 5

Rolling Regressions: Response of Export Prices to NEER ${ }^{\star}$ (continued)

Canada

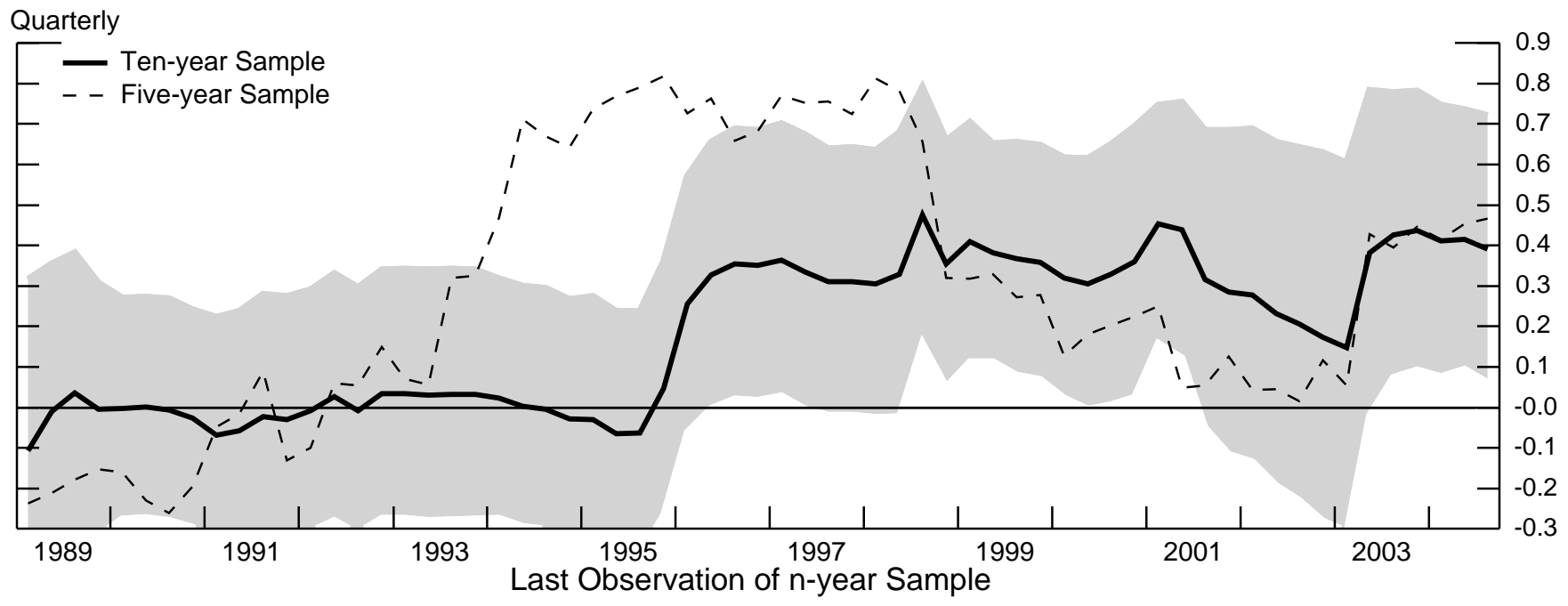

Asian NIEs

Quarterly

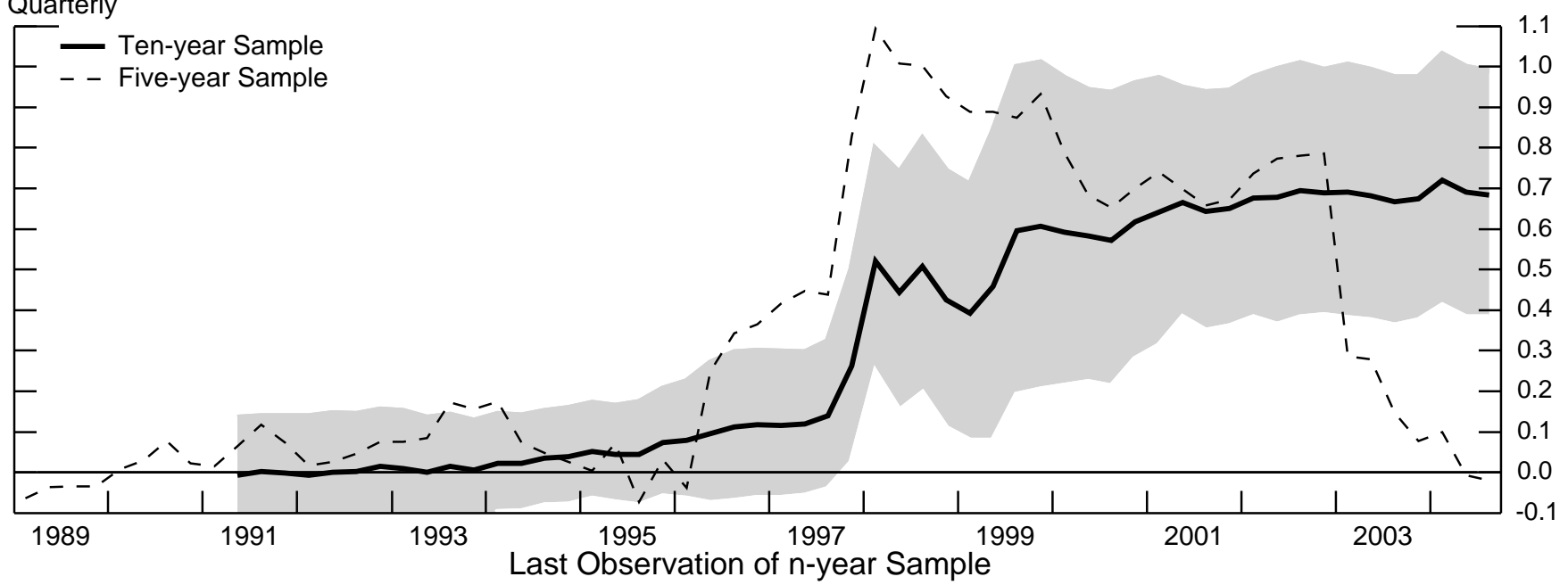

United States

Quarterly

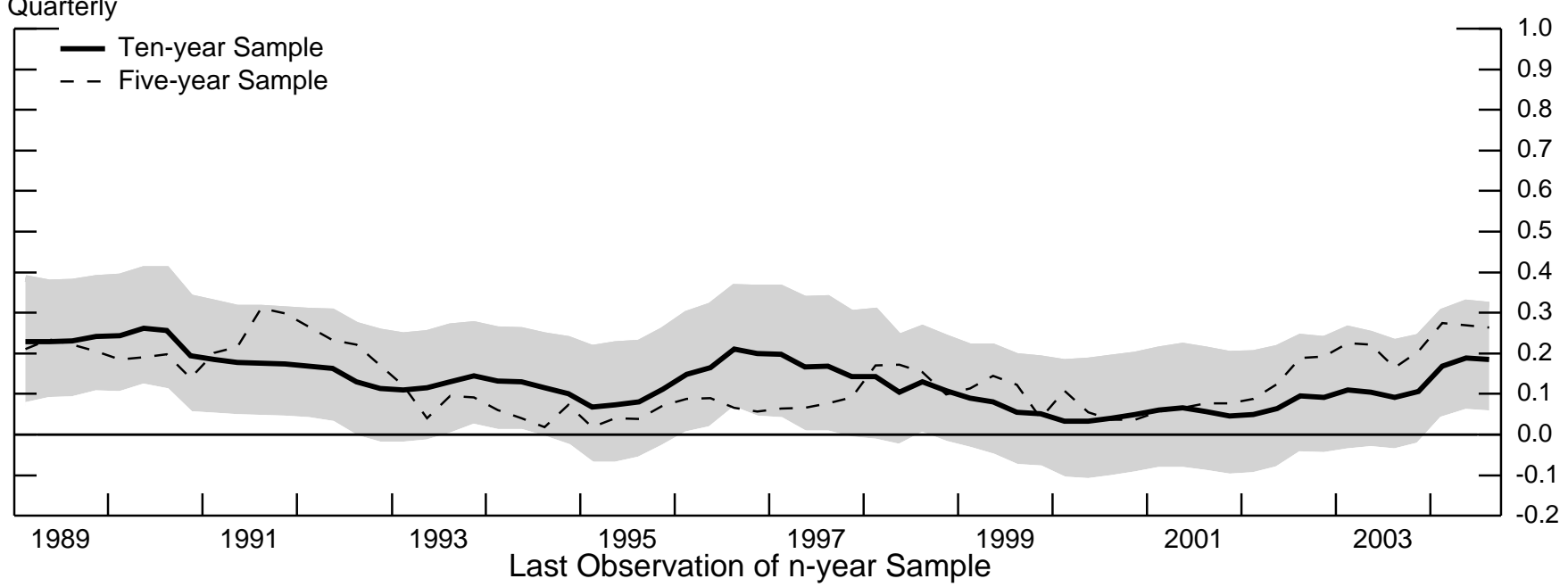

*Gray bands represent $95 \%$ confidence interval for ten-year sample. 


\section{Rolling Regressions: Response of U.S. Import Prices to NEER}

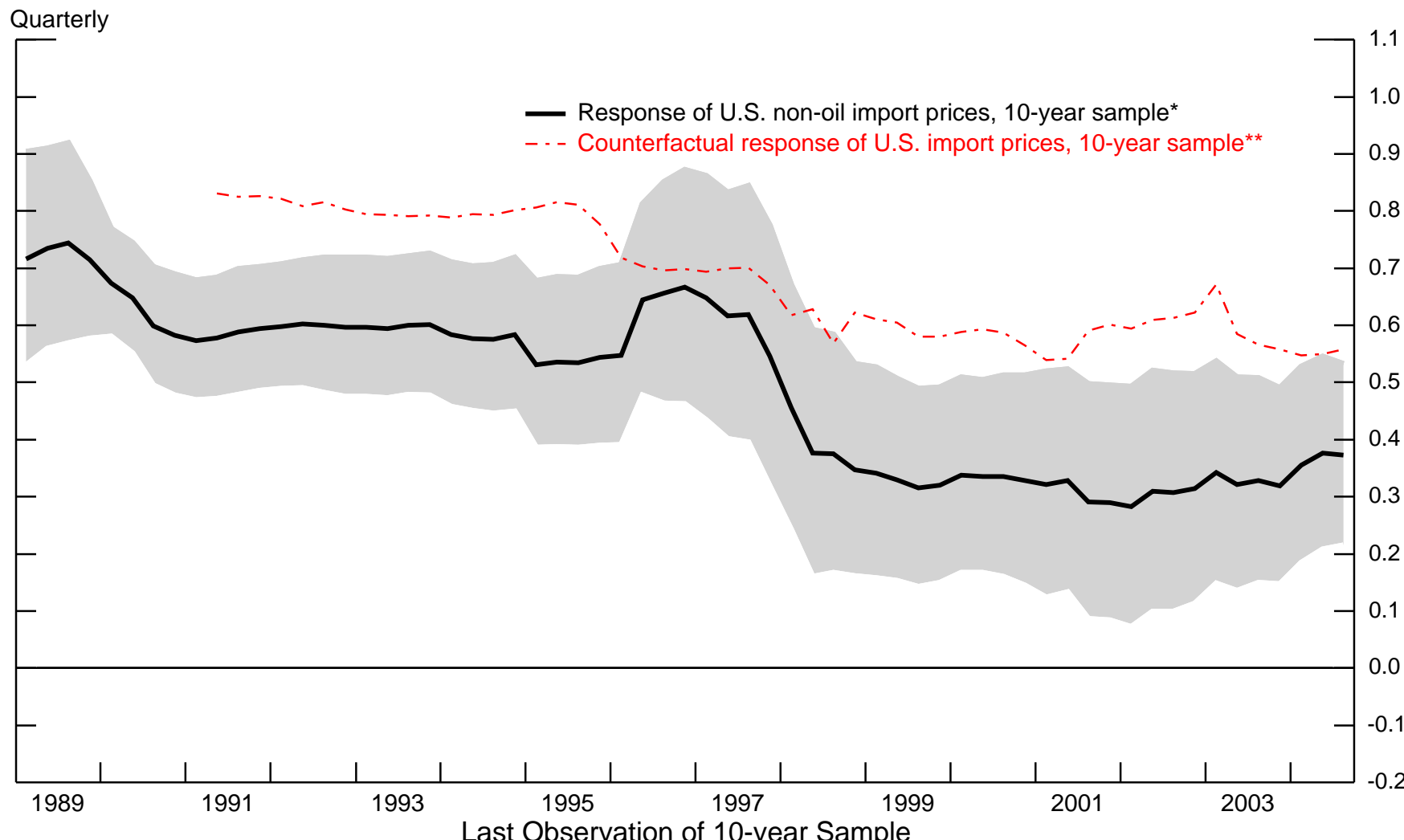

${ }^{*}$ Gray bands represent $95 \%$ confidence interval.

${ }^{\star}$ Based on multilateral export price responses of Asian NIEs, Canada, Germany, Japan, and the United Kingdom; weights reflect the share of each country/region in U.S. non-oil imports and are normalized to one.

Quarterly

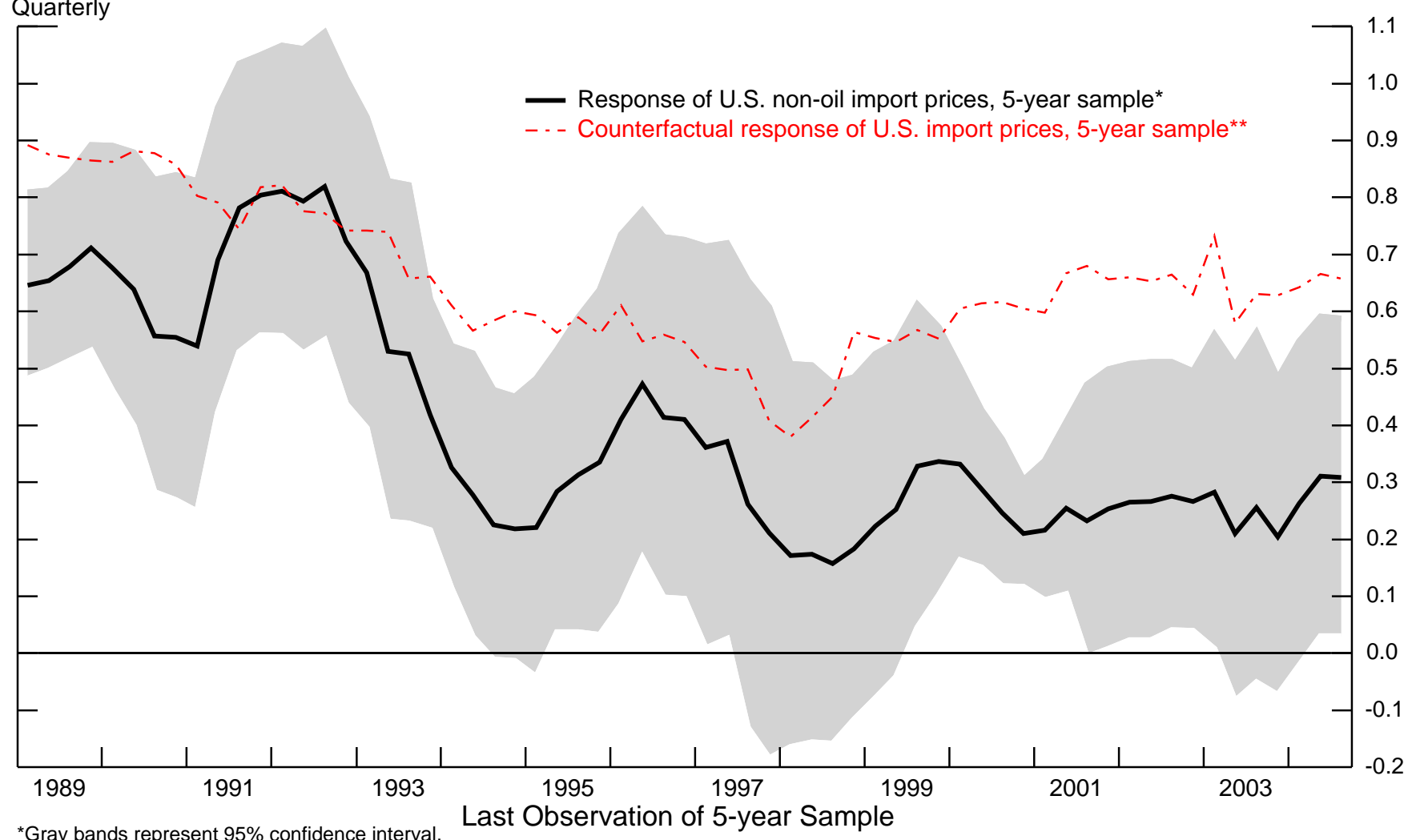

*Gray bands represent $95 \%$ confidence interval.

${ }^{*}$ Based on multilateral export price responses of Asian NIEs, Canada, Germany, Japan, and the United Kingdom; weights reflect the share of each country/region in U.S. non-oil imports and are normalized to one. 
Table 1

\section{Foreign Export Prices and Unit Labor Costs}

(Percent Change)

\begin{tabular}{|c|c|c|c|c|c|c|}
\hline & \multicolumn{3}{|c|}{ 1995:Q2 to 2002:Q1 } & \multicolumn{3}{|c|}{ 2002:Q1 to 2004:Q4 } \\
\hline & $\begin{array}{c}\text { Export } \\
\text { Prices } \\
(1) \\
\end{array}$ & $\begin{array}{c}\text { Unit Labor } \\
\text { Costs } \\
(2)\end{array}$ & $\begin{array}{l}\text { Difference } \\
(3)=(1)-(2)\end{array}$ & $\begin{array}{c}\text { Export } \\
\text { Prices } \\
(4) \\
\end{array}$ & $\begin{array}{c}\text { Unit Labor } \\
\text { Costs } \\
(5)\end{array}$ & $\begin{array}{l}\text { Difference } \\
(6)=(4)-(5) \\
\end{array}$ \\
\hline \multicolumn{7}{|l|}{ European Union } \\
\hline Bilateral U.S. Total & 45.9 & 7.8 & 38.2 & -21.4 & 2.1 & -23.5 \\
\hline Bilateral U.S. Manuf. & 45.7 & 7.8 & 37.9 & -22.7 & 2.1 & -24.8 \\
\hline Multilateral & 19.4 & 7.8 & 11.6 & -4.9 & 2.1 & -7.0 \\
\hline \multicolumn{7}{|l|}{ Japan } \\
\hline Bilateral U.S. & 34.3 & -6.5 & 40.8 & -20.4 & -12.9 & -7.5 \\
\hline Multilateral & 4.8 & -6.5 & 11.3 & -8.9 & -12.9 & 4.0 \\
\hline \multicolumn{7}{|l|}{ Canada } \\
\hline Bilateral U.S. Total & 17.7 & 3.8 & 13.9 & -5.8 & -1.1 & -4.7 \\
\hline Bilateral U.S. Manuf. & 15.6 & 3.8 & 11.8 & -14.2 & -1.1 & -13.1 \\
\hline Multilateral & 2.9 & 3.8 & -0.9 & 0.6 & -1.1 & 1.7 \\
\hline \multicolumn{7}{|l|}{ Asian NIEs* } \\
\hline Bilateral U.S. & 7.3 & -6.6 & 13.9 & -13.0 & -2.4 & -10.6 \\
\hline Multilateral & -5.3 & -6.6 & 1.3 & 2.3 & -2.4 & 4.7 \\
\hline
\end{tabular}

* Includes Hong Kong, Korea, Singapore, and Taiwan; unit labor costs are for Korea.

Source: Bilateral import prices are from the BLS (expressed in terms of exporter's currency); multilateral export prices are from country sources; unit labor costs are from OECD. 
Table 2

\section{Response of Foreign Multilateral Export Prices to NEER}

\begin{tabular}{|c|c|c|c|c|c|c|c|c|}
\hline & \multicolumn{2}{|c|}{ Exchange Rate } & \multicolumn{2}{|c|}{ Exporting Country's Prices } & \multirow{3}{*}{$\begin{array}{l}\mathrm{R}^{2} \\
(5)\end{array}$} & \multirow{3}{*}{$\begin{array}{c}\text { Start Date } \\
(6)\end{array}$} & \multirow{3}{*}{$\begin{array}{c}\text { End Date } \\
(7)\end{array}$} & \multirow{3}{*}{$\begin{array}{c}\text { Homogeneity Test } \\
\text { T Value* }^{*} \\
(8)\end{array}$} \\
\hline & Response & Confidence & Response & Confidence & & & & \\
\hline & & Band (95\%) & & Band (95\%) & & & & \\
\hline & & & & & & & & \\
\hline \multirow{2}{*}{\multicolumn{9}{|c|}{$\begin{array}{l}\text { European Union } \\
\text { Of Which: }\end{array}$}} \\
\hline & & & & & & & & \\
\hline Germany & 0.04 & $(0.02,0.07)$ & 0.83 & $(0.72,0.94)$ & 0.81 & 1980:Q1 & 2004:Q4 & -2.43 \\
\hline United Kingdom & 0.31 & $(0.19,0.42)$ & 0.22 & $(0.09,0.35)$ & 0.40 & 1980:Q2 & 2004:Q4 & -7.03 \\
\hline Japan & 0.47 & $(0.41,0.53)$ & 0.35 & $(0.11,0.59)$ & 0.87 & 1980:Q1 & 2004:Q4 & -1.49 \\
\hline Canada & 0.29 & $(0.09,0.49)$ & 0.31 & $(-0.09,0.72)$ & 0.21 & 1980:Q1 & 2004:Q4 & -1.62 \\
\hline Asian NIEs & 0.24 & $(0.08,0.41)$ & 1.01 & $(0.68,1.33)$ & 0.53 & 1981:Q3 & 2004:Q4 & 1.45 \\
\hline Memo: & & & & & & & & \\
\hline United States & 0.16 & $(0.08,0.24)$ & 0.72 & $(0.53,0.92)$ & 0.43 & 1980:Q1 & 2004:Q4 & -1.12 \\
\hline
\end{tabular}

${ }^{*}$ Bold indicates significance at $95 \%$ level. 
Table 3

Response of Foreign Multilateral Export Prices to U.S. Dollar

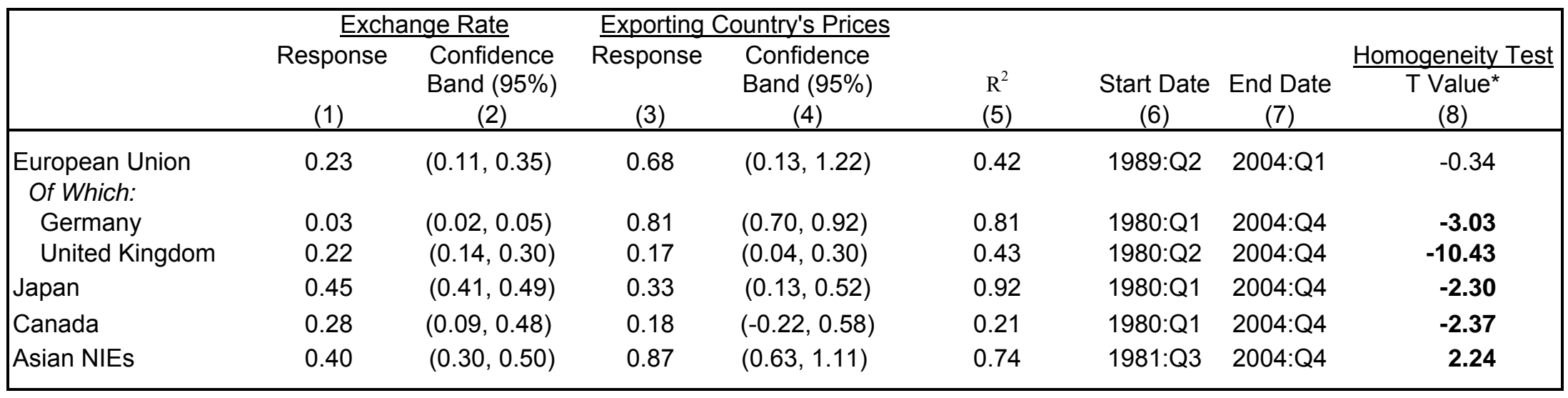

*Bold indicates significance at $95 \%$ level.

\begin{tabular}{|c|c|c|c|c|c|}
\hline & $\begin{array}{c}\text { Exch } \\
\text { Response } \\
(1)\end{array}$ & $\begin{array}{c}\text { nge Rate } \\
\text { Confidence } \\
\text { Band (95\%) } \\
(2)\end{array}$ & $\begin{array}{l}\mathrm{R}^{2} \\
(3)\end{array}$ & $\begin{array}{c}\text { Start } \\
\text { Date } \\
(4)\end{array}$ & $\begin{array}{l}\text { End } \\
\text { Date } \\
\text { (5) }\end{array}$ \\
\hline $\begin{array}{l}\text { European Union } \\
\text { Of Which: }\end{array}$ & 0.23 & $(0.11,0.35)$ & 0.35 & 1989:Q2 & 2004:Q1 \\
\hline $\begin{array}{l}\text { Germany } \\
\text { United Kingdom }\end{array}$ & $\begin{array}{l}0.09 \\
0.27\end{array}$ & $\begin{array}{l}(0.06,0.12) \\
(0.20,0.34)\end{array}$ & $\begin{array}{l}0.36 \\
0.37\end{array}$ & $\begin{array}{l}\text { 1980:Q1 } \\
\text { 1980:Q2 }\end{array}$ & $\begin{array}{l}2004: Q 4 \\
2004: Q 4\end{array}$ \\
\hline Japan & 0.47 & $(0.43,0.51)$ & 0.90 & 1980:Q1 & 2004:Q4 \\
\hline Canada & 0.30 & $(0.10,0.49)$ & 0.17 & 1980:Q1 & 2004:Q4 \\
\hline Asian NIEs & 0.47 & $(0.34,0.60)$ & 0.53 & 1981:Q3 & 2004:Q4 \\
\hline
\end{tabular}


Table 4

Response of Export Prices in U.S. Market to U.S. Dollar**

\begin{tabular}{|c|c|c|c|c|c|c|c|c|}
\hline & $\begin{array}{c}\text { Excha } \\
\text { Response } \\
\text { (1) }\end{array}$ & $\begin{array}{l}\text { nge Rate } \\
\text { Confidence } \\
\text { Band (95\%) } \\
(2)\end{array}$ & $\begin{array}{c}\text { Exporting } \\
\text { Response } \\
\text { (3) }\end{array}$ & $\begin{array}{c}\text { ountry's Prices } \\
\text { Confidence } \\
\text { Band (95\%) } \\
(4)\end{array}$ & $\begin{array}{l}\mathrm{R}^{2} \\
(5)\end{array}$ & $\begin{array}{c}\text { Start Date } \\
(6)\end{array}$ & $\begin{array}{c}\text { End Date } \\
\text { (7) }\end{array}$ & $\begin{array}{c}\text { Homogeneity Test } \\
\text { T Value } \\
(8)\end{array}$ \\
\hline \multicolumn{9}{|l|}{ European Union } \\
\hline Total & 0.70 & $(0.64,0.77)$ & 0.32 & $(0.04,0.60)$ & 0.95 & 1991:Q1 & 2004:Q3 & 0.16 \\
\hline Manufacturing & 0.70 & $(0.64,0.76)$ & 0.15 & $(-0.10,0.40)$ & 0.96 & 1991:Q1 & 2004:Q3 & -1.14 \\
\hline Japan & 0.78 & $(0.72,0.83)$ & -0.11 & $(-0.63,0.40)$ & 0.98 & 1991:Q1 & 2004:Q3 & -1.28 \\
\hline \multicolumn{9}{|l|}{ Canada } \\
\hline Total & 0.73 & $(0.42,1.04)$ & 0.09 & $(-1.11,1.29)$ & 0.53 & 1991:Q1 & 2004:Q3 & -0.29 \\
\hline Manufacturing & 0.79 & $(0.65,0.94)$ & 0.33 & $(-0.24,0.89)$ & 0.85 & 1991:Q1 & 2004:Q3 & 0.40 \\
\hline Asian NIEs & 0.78 & $(0.71,0.86)$ & 0.26 & $(0.07,0.44)$ & 0.95 & 1991:Q1 & 2004:Q3 & 0.43 \\
\hline
\end{tabular}

${ }^{*}$ Bold indicates significance at $95 \%$ level.

${ }^{*}$ BLS bilateral import price index expressed in terms of exporting-country's currency.

\section{Response of Foreign Multilateral Export Prices to NEER}

\begin{tabular}{|c|c|c|c|c|c|c|c|c|}
\hline & \multicolumn{2}{|c|}{ Exchange Rate } & \multicolumn{2}{|c|}{ Exporting Country's Prices } & \multirow[b]{2}{*}{$\begin{array}{l}\mathrm{R}^{2} \\
(5)\end{array}$} & \multirow[b]{2}{*}{$\begin{array}{l}\text { Start Date } \\
\text { (6) }\end{array}$} & \multirow[b]{2}{*}{$\begin{array}{c}\text { End Date } \\
\text { (7) }\end{array}$} & \multirow[b]{2}{*}{$\begin{array}{c}\text { Homogeneity Test } \\
\text { T Value } \\
\text { (8) }\end{array}$} \\
\hline & $\begin{array}{c}\text { Response } \\
\text { (1) }\end{array}$ & $\begin{array}{c}\text { Confidence } \\
\text { Band }(95 \%) \\
(2)\end{array}$ & $\begin{array}{c}\text { Response } \\
\text { (3) }\end{array}$ & $\begin{array}{c}\text { Confidence } \\
\text { Band (95\%) } \\
(4)\end{array}$ & & & & \\
\hline European Union & 0.32 & $(0.11,0.53)$ & 0.69 & $(0.07,1.31)$ & 0.35 & 1991:Q2 & 2004:Q1 & 0.03 \\
\hline Japan & 0.49 & $(0.40,0.59)$ & 0.29 & $(-0.61,1.18)$ & 0.85 & 1991:Q2 & 2004:Q4 & -0.48 \\
\hline Canada & 0.46 & $(0.21,0.72)$ & 1.18 & $(0.05,2.30)$ & 0.40 & 1991:Q2 & 2004:Q4 & 1.07 \\
\hline Asian NIEs & 0.54 & $(0.25,0.82)$ & 1.04 & $(0.59,1.49)$ & 0.67 & 1991:Q2 & 2004:Q4 & 2.68 \\
\hline
\end{tabular}

*Bold indicates significance at $95 \%$ level. 
Table 5

Tests for Structural Breaks

\begin{tabular}{|c|c|c|c|c|c|c|c|c|}
\hline & & fore Brea & & & fter Break & & & \\
\hline & $\begin{array}{c}\text { Constant } \\
(1)\end{array}$ & $\begin{array}{c}\text { Exnom } \\
(2)\end{array}$ & $\begin{array}{l}\text { PPI } \\
(3)\end{array}$ & $\begin{array}{c}\text { Constant } \\
(4)\end{array}$ & $\begin{array}{c}\text { Exnom } \\
(5)\end{array}$ & $\begin{array}{l}\text { PPI } \\
(6)\end{array}$ & \begin{tabular}{|c} 
Break Date \\
$(7)$
\end{tabular} & $\begin{array}{c}\text { F-stat }{ }^{\star \star} \\
(8)\end{array}$ \\
\hline Asian NIEs & 0.0019 & 0.0431 & 0.5296 & -0.0081 & 0.7173 & 1.2920 & 1997:Q3 & 16.29 \\
\hline Canada & 0.0041 & 0.2395 & 0.0595 & -0.0103 & 0.3504 & 2.6067 & 2001:Q2 & 3.98 \\
\hline Germany & 0.0034 & -0.0088 & 0.6721 & 0.0007 & 0.0595 & 0.7009 & 1985:Q2 & 4.28 \\
\hline Japan & 0.0055 & 0.4688 & 0.1486 & -0.0004 & 0.6309 & 1.3025 & 1998:Q1 & 6.70 \\
\hline United Kingdom & 0.0121 & 0.2975 & 0.1989 & -0.0009 & 0.2953 & 0.1437 & 1994:Q2 & 8.51 \\
\hline United States & 0.0187 & 0.5482 & 0.3938 & 0.0022 & 0.1067 & 0.6212 & 1985:Q2 & 2.98 \\
\hline
\end{tabular}

*Italics indicates--conditioning on a break being present--a rejection of the null hypothesis that these coefficients are equal before and after the break.

Critical values are taken from a standard normal distribution, which is valid assuming that there is a break.

**Bold indicates rejection of the null hypothesis of no break using a 95\% critical value, which is taken from Stock and Watson (2003, p. 471). 